\title{
Antinociceptive properties in mice of a lectin isolated from the marine alga Amansia multifida Lamouroux
}

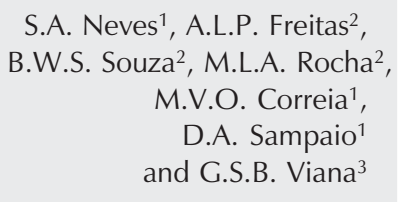

S.A. Neves ${ }^{1}$, A.L.P. Freitas ${ }^{2}$, B.W.S. Souza ${ }^{2}$, M.L.A. Rocha², M.V.O. Correia ${ }^{1}$

D.A. Sampaio ${ }^{1}$ and G.S.B. Viana ${ }^{3}$

\author{
${ }^{1}$ Departamento de Biofisiologia, Faculdade de Medicina de Juazeiro do Norte, \\ Juazeiro do Norte, CE, Brasil \\ ${ }^{2}$ Departamento de Bioquímica e Biologia Molecular, \\ ${ }^{3}$ Departamento de Fisiologia e Farmacologia, Universidade Federal do Ceará, \\ Fortaleza, CE, Brasil
}

\section{Correspondence}

G.S.B. Viana

Departamento de Fisiologia

e Farmacologia, UFC

Rua Barbosa de Freitas, 130/1100

60170-020 Fortaleza, CE

Brasil

Fax: +55-85-3242-3064

E-mail: osorio@roadnet.com.br

Research supported by CNPq.

Received March 20, 2006 Accepted November 1, 2006

\section{Abstract}

The antinociceptive effects of a lectin (LEC) isolated from the marine alga Amansia multifida were determined in Swiss mice. The LEC (1, 5 , and $10 \mathrm{mg} / \mathrm{kg}$ ) inhibited acetic acid-induced abdominal writhings in a dose-dependent manner after intraperitoneal or oral administration. A partial but significant inhibition of writhings was observed after the combination of LEC $(10 \mathrm{mg} / \mathrm{kg})$ with avidin $(1 \mathrm{mg} / \mathrm{kg})$, a potent inhibitor of the hemmaglutinant activity of the lectin. However, total writhing inhibition was demonstrable in the group of mice treated with LEC plus mannose ( $1 \mathrm{mg} / \mathrm{kg}$ ), as compared to LEC alone or to control groups. Furthermore, avidin and mainly mannose also play a role in antinociception, somehow facilitating the interaction of LEC with its active cell sites. In the formalin test, although both phases of the response were significantly inhibited, the effect of LEC was predominant during phase 2, causing inhibition of licking time that ranged from 48 to $88 \%$ after oral ( 5 and $10 \mathrm{mg} / \mathrm{kg}$ ) and intraperitoneal (1 to 5 $\mathrm{mg} / \mathrm{kg}$ ) administration. As is the case with morphine, the effect of LEC $(2 \mathrm{mg} / \mathrm{kg})$ was reversed by naloxone $(2 \mathrm{mg} / \mathrm{kg})$, indicating the involvement of the opioid system. LEC was also effective in the hotplate test, producing inhibitory responses to the thermal stimulus, and its effects were blocked by naloxone. In the pentobarbital-induced sleeping time, although LEC did not alter the onset of sleep significantly, it increased the time of sleep within the same dose range compared to control. These results show that LEC presents antinociceptive effects of both central and peripheral origin, possibly involving the participation of the opioid system.

\section{Introduction}

Lectins are proteins or glycoproteins usually of plant origin, of a non-immunoglobulin nature. They are capable of specifically recognizing carbohydrate moieties and of
Key words

- Red algae

- Amansia multifida

- Lectin

- Antinociceptive effects

- Mannose-specific lectin reversing their own binding to complex glycoconjugates, without altering the covalent structure of any of the glycosyl ligands they recognize. Lectins also have the property of binding to sugars on cell membranes, thereby changing the physiology of the membrane, 
leading to agglutination, mitosis, or other biochemical changes in the cell.

Many members of the lectin family agglutinate red blood cells and, after purification, are used to determine blood type. The agglutination of erythrocytes is due to their binding to the $\mathrm{N}$-acetyl-D-galactosamine moieties of cell membranes. Lectins act as mitogens of $\mathrm{T}$ and $\mathrm{B}$ lymphocytes both in humans and animals. They also cause cancer cell agglutination. They damage enterocytes of the duodenum and cecum epithelium, lower the activity of proteolytic enzymes, and cause morphological changes in the kidney and liver (1). Lectins can be inactivated by specific carbohydrates such as monoand oligosaccharides that prevent the protein from attaching to carbohydrates on the surface of the cell membrane.

Although marine algal lectins show a proteinaceous content similar to that of plant lectins, they differ in some aspects. Early publications have reported that, in general, lectins from algae have low molecular masses, no affinity for monosaccharides, and strong specificity for complex oligosaccharides and/or glycoproteins. Moreover, they do not appear to require metal ions, showing a high content of acidic residues and, even at high concentrations, tend to stay in the monomeric form (2-4). It has been shown (5) that aqueous extracts of the red marine algae Hypnea musciformis and H. cervicornis present hemagglutinating activity, and a recent study (6) reported the purification and characterization of a new lectin from $\mathrm{H}$. musciformis that agglutinates erythrocytes from various sources.

An earlier (7) study performed with extracts of several marine algae including Amansia multifida demonstrated that these extracts possess antinociceptive activity, and this activity was also observed in a recent investigation (8) of a crude protein fraction (F0/60) and a lectin-rich chromatographic fraction (PII-DEAE) from the red marine algae Bryothamnion seaforthii. The objec- tives of the present study were to demonstrate whether the lectin from A. multifida also presents antinociceptive properties, and to elucidate its mechanism of action.

\section{Material and Methods}

\section{Drugs and reagents}

Bovine serum albumin, naloxone and sodium pentobarbital were purchased from Sigma (St. Louis, MO, USA). Morphine sulfate was from Cristália do Brasil S/A (Itapira, SP, Brazil). Formaldehyde was purchased from Reagen (São Paulo, SP, Brazil), and acetic acid from Vetec (São Paulo, SP, Brazil). All other drugs and reagents used were of analytical grade.

\section{Plant material}

A. multifida was collected on the Northeastern Brazilian coast (Fleixeiras Beach, Trairi, Ceará State, Brazil), brought to the laboratory in water and ice bags, and kept at $-20^{\circ} \mathrm{C}$ until use. The alga was identified by Ms. F.H.F. Costa (Universidade Federal do Ceará, Fortaleza, CE, Brazil), and a sample was deposited in the Prisco Bezerra Herbarium of the Federal University of Ceará (Voucher No. 32,186).

\section{Purification}

Briefly, algae were thawed, rinsed with distilled water, ground to a fine powder under liquid nitrogen, stirred for $4 \mathrm{~h}$ with 3 volumes of $20 \mathrm{mM}$ phosphate buffer, $\mathrm{pH}$ 7.0 , containing $0.15 \mathrm{M} \mathrm{NaCl}$, filtered through a nylon mesh, and centrifuged at 7,000 $\mathrm{g}$ for $30 \mathrm{~min}$ at $4^{\circ} \mathrm{C}$. Ammonium sulfate crystals were added to the supernatant to $70 \%$ saturation. After $16 \mathrm{~h}$, the precipitate was recovered by centrifugation (F0/70), resuspended in distilled water, and dialyzed (9). Fractions containing lectins (PI and PII) were obtained by lyophilization of F0/70, followed by 
DEAE-Sephacel chromatography. The column was equilibrated and PI was eluted with $20 \mathrm{mM}$ sodium phosphate buffer, $\mathrm{pH}$ 7.0, followed by the elution of PII with $1 \mathrm{M}$ $\mathrm{NaCl}$. Active fractions (PI and PII) were dialyzed against water and lyophilized. The procedure for isolation of the fraction containing lectins is a simple and reproducible one, and provides an average yield of 10-15 $\mathrm{mg}$ of protein per kilogram of fresh algae. In the present study, only the PI fraction was used, and this fraction containing lectin (LEC) was identified by the hemagglutinating reaction and dissolved in distilled water before use. The degree of purity of PI was evaluated by polyacrylamide gel electrophoresis in the presence of sodium dodecyl sulfate and 2-mercaptoethanol. The electrophoretic profile showed a single band with an apparent molecular mass of $30 \mathrm{kDa}(9)$.

\section{Animals}

Swiss mice of both sexes, weighing 20 to $25 \mathrm{~g}$, from the Animal House of the Federal University of Ceará, maintained on a 12-h light/dark cycle with free access to water and food, were used. Since LEC was dissolved in distilled water, this vehicle was used for all control groups. Experiments were carried out according to the Guide for the Care and Use of Laboratory Animals, of the US Health and Human Services Department.

\section{Evaluation of antinociceptive activity}

Writhing test. This test is used for the evaluation of analgesic activity. Male and female mice were treated with LEC $(1,5$, and $10 \mathrm{mg} / \mathrm{kg}$, intraperitoneally (ip), or 0.5 , 1,5 , and $10 \mathrm{mg} / \mathrm{kg}$, orally (po)), $30 \mathrm{~min}$ (ip) or $60 \mathrm{~min}(p o)$, before receiving a $0.6 \%$ acetic acid injection $(10 \mathrm{~mL} / \mathrm{kg}$, ip $)$. The number of contractions or writhings, determined by abdominal muscle contractions and hind paw extension was recorded for 20 min, starting 10 min after the administration of acetic acid (10). Naloxone $(2 \mathrm{mg} / \mathrm{kg}$, subcutaneously, sc) was injected 15 min before LEC $(2 \mathrm{mg} / \mathrm{kg}$ ) or morphine $(5 \mathrm{mg} / \mathrm{kg}$, ip), used as standard.

Formalin test. This test, which causes a local tissue injury to the paw, has been used as a model for tonic pain and localized inflammatory pain. For this, $20 \mu \mathrm{L}$ of a $1 \%$ formalin solution was injected into the right hind paw of male Swiss mice ( $25 \mathrm{~g}$ ), and the licking time was recorded after the first 5 min (1st phase, corresponding to a direct chemical stimulation of nociceptors) and after 20 min (2nd phase, involving inflammation), for $5 \mathrm{~min}$ each time. Animals were pretreated with LEC $30 \mathrm{~min}$ (ip) or $60 \mathrm{~min}$ (po) before intraplantar formalin injection. Naloxone, an opioid antagonist, was injected 15 min before LEC, and morphine was used as standard $(11,12)$.

Hot-plate test. In this test which measures analgesic activity, male Swiss mice (25 g) were pre-selected according to their reactions to a thermal stimulus (jumping or licking of hind limbs when placed on a hot plate at $55^{\circ} \mathrm{C}$ ). Latency times were recorded immediately before and 30, 60, 90, and 120 min after drug administration, up to a maximum time of $40 \mathrm{~s}$ to avoid paw lesions (13). For the detection of a possible involvement of the opioid system, animals were pretreated with naloxone 15 min before treatment with LEC or morphine.

Barbiturate-induced sleeping time. This test is used to determine hypnotic and sedative effects. Central nervous system depressor drugs, in general, reduce the latency and/ or increase the sleep duration time. Sleep was induced in female mice by ip administration of $40 \mathrm{mg} / \mathrm{kg}$ sodium pentobarbital by the method of Ferrini et al. (14). Sodium pentobarbital was injected $30 \mathrm{~min}$ (ip) or 60 min (po) after the administration of LEC, and the latency time to sleep (time to lose the righting reflex) and the sleeping time (duration of time to recover the righting reflex) were determined. 


\section{Statistical analysis}

Data are reported as means \pm SEM. Data were analyzed by ANOVA followed by the Student-Newman-Keuls as a post hoc test, with the level of significance set at $\mathrm{P}<0.05$.

\section{Results}

In the writhing test, $\operatorname{LEC}(1,5$, and 10 $\mathrm{mg} / \mathrm{kg}$ ) inhibited in a dose-dependent man-

Table 1. Inhibitory effect of LEC, a lectin from Amansia multifida, in mice submitted to the writhing test.

\begin{tabular}{lrc}
\hline Dose/route of administration & $\begin{array}{c}\text { Number of contractions } \\
(20 \mathrm{~min})\end{array}$ & $\%$ Inhibition \\
\hline $\begin{array}{l}\text { Control }(\mathrm{N}=9) \\
\text { Distilled water } 1 \mathrm{~mL} / \mathrm{kg}, \text { po }\end{array}$ & $23.6 \pm 1.7$ & - \\
LEC & $14.3 \pm 2.3$ & $39 \%^{*}$ \\
$0.5 \mathrm{mg} / \mathrm{kg}, p o(\mathrm{~N}=9)$ & $14.0 \pm 1.9$ & $41 \%^{*}$ \\
$1 \mathrm{mg} / \mathrm{kg}, p o(\mathrm{~N}=9)$ & $9.1 \pm 1.8$ & $61 \%^{*}$ \\
$5 \mathrm{mg} / \mathrm{kg}, p o(\mathrm{~N}=9)$ & $4.0 \pm 1.7$ & $83 \%^{*}$ \\
$10 \mathrm{mg} / \mathrm{kg}, p o(\mathrm{~N}=9)$ & $17.0 \pm 1.2$ & $28 \%$ \\
$1 \mathrm{mg} / \mathrm{kg}, i p(\mathrm{~N}=15)$ & $4.9 \pm 0.6$ & $79 \%^{*}$ \\
$5 \mathrm{mg} / \mathrm{kg}, i p(\mathrm{~N}=15)$ & $3.2 \pm 0.3$ & $87 \%^{*}$ \\
$10 \mathrm{mg} / \mathrm{kg}, i p(\mathrm{~N}=15)$ &
\end{tabular}

Data are reported as means \pm SEM for the number of animals shown in parentheses. ${ }^{*} \mathrm{P}<0.05$ compared to control (ANOVA followed by the post hoc Student-NewmanKeuls test).

Table 2. Effect of LEC, a lectin from Amansia multifida, and the possible involvement of mannose and avidin in antinociception in mice submitted to the writhing test.

\begin{tabular}{lcc}
\hline Dose $/$ route of administration & $\begin{array}{c}\text { Number of contractions } \\
(20 \mathrm{~min})\end{array}$ & $\%$ Inhibition \\
\hline Control, distilled water $1 \mathrm{~mL} / \mathrm{kg}$, ip $(\mathrm{N}=11)$ & $27.6 \pm 1.63$ & - \\
Avidin $1 \mathrm{mg} / \mathrm{kg}, i p(\mathrm{~N}=12)$ & $21.2 \pm 1.12$ & $23 \%$ \\
Mannose $1 \mathrm{mg} / \mathrm{kg}, i p(\mathrm{~N}=14)$ & $18.8 \pm 1.6$ & $32 \%$ \\
LEC $10 \mathrm{mg} / \mathrm{kg}, p o(\mathrm{~N}=12)$ & $5.6 \pm 0.8$ & $80 \%^{*}$ \\
LEC $10 \mathrm{mg} / \mathrm{kg}, i p(\mathrm{~N}=12)$ & $4.1 \pm 1.0$ & $85 \%^{*}$ \\
LEC $10 \mathrm{mg} / \mathrm{kg}, p o$ & & $51 \%^{*}$ \\
$\quad+$ avidin $1 \mathrm{mg} / \mathrm{kg}, p o(\mathrm{~N}=13)$ & $13.5 \pm 1.2$ & $67 \%^{*}$ \\
LEC $10 \mathrm{mg} / \mathrm{kg}, i p$ & & \\
$\quad+$ avidin $1 \mathrm{mg} / \mathrm{kg}, i p(\mathrm{~N}=13)$ & $9.1 \pm 1.6$ & $17 \%$ \\
LEC $10 \mathrm{mg} / \mathrm{kg}, p o$ & & \\
$\quad+$ mannose $1 \mathrm{mg} / \mathrm{kg}, p o(\mathrm{~N}=14)$ & $22.9 \pm 1.2$ & $12 \%$ \\
LEC $10 \mathrm{mg} / \mathrm{kg}, i p$ & &
\end{tabular}

Data are reported as means \pm SEM for the number of animals shown in parentheses. ${ }^{*} \mathrm{P}<0.05$ compared to control (ANOVA and post hoc Student-Newman-Keuls test). ner the acetic acid-induced abdominal constrictions in mice after ip $(28,79$, and $87 \%$ inhibition, respectively) and po $(41,61$, and $83 \%$ ) administration (Table 1). In order to show a possible involvement of avidin (a potent inhibitor of the lectin hemmagglutinant activity) in the antinociceptive effects of LEC, the writhing test was performed before and after the interaction of LEC with avidin. While LEC alone $(10 \mathrm{mg} / \mathrm{kg}$, po and ip) inhibited writhing in 80 and $85 \%$, respectively, the inhibition was somewhat lesser (51 and 67\%) in groups treated with LEC plus avidin $(1 \mathrm{mg} / \mathrm{kg})$ as compared to controls (Table 2). Furthermore, the presence of mannose $(1 \mathrm{mg} / \mathrm{kg})$ residues in the LEC molecule led us to perform the writhing test with LEC in the absence and in the presence of D-mannose. In contrast to the results observed with LEC in the presence of avidin, almost no inhibition of writhing was observed in the group treated with LEC (10 $\mathrm{mg} / \mathrm{kg}$, po or ip) plus mannose $(1 \mathrm{mg} / \mathrm{kg})$ as compared to LEC alone, and the values were close to those of controls.

In the formalin test (Table 3), although both phases of the response were significantly inhibited, the LEC effect was predominant in phase 2, causing 61 and $48 \%$ inhibition of licking time at the doses of 5 and $10 \mathrm{mg} / \mathrm{kg}$, po, and 60, 88, and $69 \%$ inhibition after ip administration of 1,2 , and $5 \mathrm{mg} / \mathrm{kg}$, respectively. Similarly to morphine, the LEC effect was almost completely reversed by the previous administration of naloxone $(2 \mathrm{mg} / \mathrm{kg}, s c)$, indicating the involvement of the opioid system in the antinociceptive effect of LEC (Table 4).

The hot-plate test was performed for the assessment of the central antinociceptive effect of LEC (Table 5). Results showed that LEC significantly inhibited the reaction time to thermal stimuli at 30,60 , and 90 min after ip administration of 1,5 , and $10 \mathrm{mg} / \mathrm{kg}$ compared to controls (LEC1, $30 \mathrm{~min}: 120 \%$; 60 min: 48\%; 90 min: 68\%; LEC5, 30 min: 50\%; 60 min: 55\%; 90 min: 72\%; LEC10, 60 
min: 28\%; 90 min: 30\%). Similar effects were observed after po administration of LEC. However, while the dose of $5 \mathrm{mg} / \mathrm{kg}$ (LEC5) caused inhibitions of the order of $99 \%$ and $66 \%$ (60 and $90 \mathrm{~min}$ ), the higher dose (LEC10, $10 \mathrm{mg} / \mathrm{kg}$ ) significantly increased the reaction time at $30 \mathrm{~min}(34 \%)$, $60 \min (91 \%)$, and $90 \mathrm{~min}(73 \%)$. As expected, morphine significantly increased the animals' latency to respond to the thermal stimuli at $30(145 \%), 60(169 \%)$, and $90 \mathrm{~min}$ $(121 \%)$ after ip injection, and its effect was blocked by naloxone. Similarly, the antinociceptive effect of LEC was also blocked by naloxone, indicating involvement of the opioid system.

In the pentobarbital-induced sleeping time, although LEC did not alter the onset of sleep, it significantly increased sleep duration. After oral administration, LEC at the doses of $0.1,0.5,5$ and $10 \mathrm{mg} / \mathrm{kg}$ did not change sleep latency or sleep duration compared to control. The exception was a small but significant increase (23\%) of the sleep duration at the dose of $0.5 \mathrm{mg} / \mathrm{kg}$. However, LEC was effective after ip administration, increasing this parameter by 35 and $55 \%$ with the doses of 5 and $10 \mathrm{mg} / \mathrm{kg}$, respec-

\begin{tabular}{|c|c|c|c|c|}
\hline \multirow[t]{2}{*}{ Dose/route of administration } & \multicolumn{2}{|c|}{ Licking time (s) } & \multicolumn{2}{|c|}{$\%$ Inhibition } \\
\hline & 1st phase & 2nd phase & 1st phase & 2nd phase \\
\hline \multicolumn{5}{|l|}{ Control $(\mathrm{N}=9)$} \\
\hline Distilled water $1 \mathrm{~mL} / \mathrm{kg}$, po & $61.4 \pm 5.4$ & $31.6 \pm 3.1$ & - & - \\
\hline \multicolumn{5}{|l|}{ LEC } \\
\hline $1 \mathrm{mg} / \mathrm{kg}, p o(\mathrm{~N}=7)$ & $65.7 \pm 3.4$ & $45.5 \pm 4.1$ & - & - \\
\hline $5 \mathrm{mg} / \mathrm{kg}, p o(\mathrm{~N}=10)$ & $72.0 \pm 4.9$ & $12.4 \pm 3.7$ & - & $61 \% *$ \\
\hline $10 \mathrm{mg} / \mathrm{kg}, p o(\mathrm{~N}=10)$ & $54.4 \pm 3.0$ & $16.6 \pm 3.2$ & $11 \%$ & $48 \%{ }^{*}$ \\
\hline \multicolumn{5}{|l|}{ Control $(\mathrm{N}=6)$} \\
\hline Distilled water $1 \mathrm{~mL} / \mathrm{kg}$, ip & $68.3 \pm 3.3$ & $33.3 \pm 3.1$ & - & - \\
\hline \multicolumn{5}{|l|}{ LEC } \\
\hline $1 \mathrm{mg} / \mathrm{kg}$, ip $(\mathrm{N}=13)$ & $50.9 \pm 4.5$ & $13.4 \pm 2.4$ & $26 \%{ }^{*}$ & $60 \%{ }^{*}$ \\
\hline $2 \mathrm{mg} / \mathrm{kg}$, ip $(\mathrm{N}=8)$ & $58.9 \pm 2.3$ & $4.0 \pm 0.92$ & $14 \%$ & $88 \%{ }^{*}$ \\
\hline $5 \mathrm{mg} / \mathrm{kg}$, ip $(\mathrm{N}=7)$ & $62.0 \pm 4.3$ & $10.5 \pm 2.7$ & $10 \%$ & $69 \%{ }^{*}$ \\
\hline
\end{tabular}

Data are reported as means \pm SEM for the number of animals shown in parentheses.

${ }^{*} \mathrm{P}<0.05$ compared to control (ANOVA followed by the post hoc Student-Newman-Keuls test).

Table 4. Possible involvement of the opioid system in the antinociceptive effect of LEC, a lectin from Amansia multifida, in mice submitted to the formalin test.

\begin{tabular}{|c|c|c|c|c|}
\hline \multirow[t]{2}{*}{ Dose/route of administration } & \multicolumn{2}{|c|}{ Licking time (s) } & \multicolumn{2}{|c|}{$\%$ Inhibition } \\
\hline & 1st phase & 2nd phase & 1st phase & 2nd phase \\
\hline Control, distilled water $1 \mathrm{~mL} / \mathrm{kg}$, ip $(\mathrm{N}=11)$ & $67.6 \pm 2.7$ & $31.5 \pm 2.5$ & - & - \\
\hline LEC $2 \mathrm{mg} / \mathrm{kg}$, ip $(\mathrm{N}=8)$ & $58.0 \pm 2.3$ & $4.0 \pm 0.9$ & $31 \% *$ & $78 \%{ }^{*}$ \\
\hline Morphine $5 \mathrm{mg} / \mathrm{kg}$, ip $(\mathrm{N}=11)$ & $27.2 \pm 3.3$ & $11.7 \pm 2.4$ & $60 \% *$ & $63 \% *$ \\
\hline \multicolumn{5}{|l|}{ LEC $2 \mathrm{mg} / \mathrm{kg}$, ip } \\
\hline + naloxone $2 \mathrm{mg} / \mathrm{kg}, \mathrm{sc}(\mathrm{N}=10)$ & $64.1 \pm 4.3$ & $24.0 \pm 3.9$ & $5 \%$ & $24 \%$ \\
\hline \multicolumn{5}{|l|}{ Morphine $5 \mathrm{mg} / \mathrm{kg}$, ip } \\
\hline + naloxone $2 \mathrm{mg} / \mathrm{kg}, \mathrm{sc}(\mathrm{N}=10)$ & $60.6 \pm 2.7$ & $29.3 \pm 4.4$ & $10 \%$ & $7 \%$ \\
\hline
\end{tabular}

Data are reported as means \pm SEM for the number of animals shown in parentheses.

${ }^{*} \mathrm{P}<0.05$ compared to control (ANOVA followed by the post hoc Student-Newman-Keuls test). 
Table 5. Effect of LEC, a lectin from Amansia multifida, in mice submitted to the hot-plate test.

\begin{tabular}{|c|c|c|c|c|}
\hline \multirow[t]{2}{*}{ Dose/route of administration } & \multicolumn{4}{|c|}{ Reaction time to the thermal stimulus (s) } \\
\hline & $0 \mathrm{~min}$ & $30 \mathrm{~min}$ & $60 \min$ & $90 \min$ \\
\hline \multicolumn{5}{|l|}{ Control $(\mathrm{N}=22)$} \\
\hline Distilled water $1 \mathrm{~mL} / \mathrm{kg}$, ip & $11.8 \pm 0.8$ & $10.6 \pm 0.9$ & $8.3 \pm 0.80$ & $9.5 \pm 0.6$ \\
\hline \multicolumn{5}{|l|}{ LEC } \\
\hline $0.1 \mathrm{mg} / \mathrm{kg}$, ip $(\mathrm{N}=9)$ & $13.6 \pm 1.3$ & $11.7 \pm 1.8$ & $\begin{array}{c}11.4 \pm 1.6 \\
(27 \%)\end{array}$ & $9.7 \pm 1.5$ \\
\hline $1 \mathrm{mg} / \mathrm{kg}$, ip $(\mathrm{N}=15)$ & $14.7 \pm 0.8$ & $\begin{array}{c}23.4 \pm 1.7 \\
(120 \%)^{*}\end{array}$ & $\begin{array}{c}13.3 \pm 0.8 \\
(48 \%)^{*}\end{array}$ & $\begin{array}{c}16.0 \pm 0.9 \\
(68 \%)^{*}\end{array}$ \\
\hline $5 \mathrm{mg} / \mathrm{kg}$, ip $(\mathrm{N}=15)$ & $14.8 \pm 1.0$ & $\begin{array}{c}15.9 \pm 0.7 \\
(50 \%)^{*}\end{array}$ & $\begin{array}{c}12.8 \pm 1.0 \\
(55 \%)^{*}\end{array}$ & $\begin{array}{c}16.3 \pm 1.0 \\
(72 \%)^{*}\end{array}$ \\
\hline $10 \mathrm{mg} / \mathrm{kg}$, ip $(\mathrm{N}=15)$ & $13.1 \pm 0.7$ & $11.0 \pm 1.1$ & $\begin{array}{c}10.6 \pm 1.1 \\
(28 \%)^{\star}\end{array}$ & $\begin{array}{c}12.3 \pm 1.2 \\
(30 \%)^{*}\end{array}$ \\
\hline \multicolumn{5}{|l|}{ LEC } \\
\hline $1 \mathrm{mg} / \mathrm{kg}, p o(\mathrm{~N}=10)$ & $13.9 \pm 1.1$ & $8.2 \pm 0.9$ & $\begin{array}{c}10.4 \pm 1.7 \\
(26 \%)\end{array}$ & $7.5 \pm 0.9$ \\
\hline $5 \mathrm{mg} / \mathrm{kg}, p o(\mathrm{~N}=10)$ & $7.9 \pm 0.9$ & $10.5 \pm 1.1$ & $\begin{array}{c}16.4 \pm 0.8 \\
(99 \%)^{\star}\end{array}$ & $\begin{array}{c}15.8 \pm 1.2 \\
(66 \%)^{*}\end{array}$ \\
\hline $10 \mathrm{mg} / \mathrm{kg}, p o(\mathrm{~N}=10)$ & $10.9 \pm 1.2$ & $\begin{array}{c}14.3 \pm 0.8 \\
(34 \%)^{*}\end{array}$ & $\begin{array}{c}15.8 \pm 1.1 \\
(91 \%)^{*}\end{array}$ & $\begin{array}{c}16.4 \pm 1.1 \\
(73 \%)^{*}\end{array}$ \\
\hline Morphine $5 \mathrm{mg} / \mathrm{kg}$, ip $(\mathrm{N}=13)$ & $12.1 \pm 0.9$ & $\begin{array}{c}25.8 \pm 1.9 \\
(145 \%)^{*}\end{array}$ & $\begin{array}{c}22.3 \pm 0.8 \\
(169 \%)^{*}\end{array}$ & $\begin{array}{c}20.3 \pm 1.9 \\
(121 \%)^{*}\end{array}$ \\
\hline \multicolumn{5}{|l|}{ LEC $1 \mathrm{mg} / \mathrm{kg}$, ip } \\
\hline + naloxone $2 \mathrm{mg} / \mathrm{kg}, s c(\mathrm{~N}=13)$ & $8.1 \pm 0.8$ & $\begin{array}{c}14.4 \pm 1.6 \\
(36 \%)^{*}\end{array}$ & $7.3 \pm 0.9$ & $6.1 \pm 1.2$ \\
\hline \multicolumn{5}{|l|}{ Morphine $5 \mathrm{mg} / \mathrm{kg}$, ip } \\
\hline + naloxone $2 \mathrm{mg} / \mathrm{kg}, s c(\mathrm{~N}=13)$ & $14.9 \pm 1.2$ & $8.3 \pm 0.8$ & $9.4 \pm 1.5$ & $7.1 \pm 1.2$ \\
\hline
\end{tabular}

Data are reported as means \pm SEM and \% of potentiation for the number of animals shown in parentheses. ${ }^{*} \mathrm{P}<0.05$ compared to control (ANOVA followed by the post hoc Student-Newman-Keuls test).

Table 6. Potentiation of the barbiturate-induced sleeping time in mice by LEC, a lectin from Amansia multifida.

\begin{tabular}{|c|c|c|c|}
\hline Dose/route of administration & $\begin{array}{c}\text { Sleep latency } \\
\text { (s) }\end{array}$ & $\begin{array}{l}\text { Sleep duration } \\
\text { (s) }\end{array}$ & $\begin{array}{c}\text { Increase of sleep } \\
\text { duration (\%) }\end{array}$ \\
\hline \multicolumn{4}{|l|}{ Control $(N=16)$} \\
\hline Distilled water $1 \mathrm{~mL} / \mathrm{kg}$, po & $270.0 \pm 18.0$ & $2154 \pm 126$ & \\
\hline \multicolumn{4}{|l|}{ LEC } \\
\hline $0.1 \mathrm{mg} / \mathrm{kg}, p o(\mathrm{~N}=7)$ & $291.0 \pm 24$ & $2256 \pm 306$ & - \\
\hline $0.5 \mathrm{mg} / \mathrm{kg}, p o(\mathrm{~N}=9)$ & $292.8 \pm 15.6$ & $2658 \pm 246$ & $23 \% *$ \\
\hline $5 \mathrm{mg} / \mathrm{kg}, p o(\mathrm{~N}=8)$ & $294.0 \pm 24.0$ & $2358 \pm 150$ & - \\
\hline $10 \mathrm{mg} / \mathrm{kg}$, po $(\mathrm{N}=9)$ & $264.0 \pm 12.0$ & $2064 \pm 246$ & - \\
\hline \multicolumn{4}{|l|}{ Control $(\mathrm{N}=8)$} \\
\hline Distilled water $1 \mathrm{~mL} / \mathrm{kg}$, ip & $210.0 \pm 13.2$ & $3189 \pm 246$ & \\
\hline \multicolumn{4}{|l|}{ LEC } \\
\hline $0.1 \mathrm{mg} / \mathrm{kg}$, ip $(\mathrm{N}=8)$ & $246.0 \pm 21$ & $3180 \pm 189.6$ & - \\
\hline $0.5 \mathrm{mg} / \mathrm{kg}$, ip $(\mathrm{N}=8)$ & $276.0 \pm 13.2$ & $3369.6 \pm 324$ & - \\
\hline $5 \mathrm{mg} / \mathrm{kg}$, ip $(\mathrm{N}=8)$ & $216.0 \pm 13.2$ & $4320 \pm 195$ & $35 \% *$ \\
\hline $10 \mathrm{mg} / \mathrm{kg}$, ip $(\mathrm{N}=9)$ & $228.0 \pm 14.4$ & $4933.2 \pm 204$ & $55 \%{ }^{*}$ \\
\hline
\end{tabular}

Data are reported as means \pm SEM sleep latency and duration (s) recorded for $3 \mathrm{~h}$. The number of animals per group is given in parentheses. Sodium pentobarbital $(40 \mathrm{mg} / \mathrm{kg}$ ) was administered either $60 \mathrm{~min}(p o)$ or 30 $\min ($ ip) after administration of LEC.

${ }^{*} \mathrm{P}<0.05$ compared to controls (ANOVA and post hoc Student-Newman-Keuls test). 
tively. No effects were detected with lower doses $(0.1$ and $0.5 \mathrm{mg} / \mathrm{kg}$ ) (Table 6).

\section{Discussion}

The native molecular mass of $26.9 \mathrm{kDa}$, as determined by size exclusion chromatography on a Superose 12R column, suggests that the lectin from the marine alga Amansia multifida Lamouroux is a monomeric glycoprotein, containing $2.9 \%$ of neutral carbohydrates as determined by the phenol-sulfuric acid method (9). Inhibition assays of the hemagglutinating activity of this lectin, using a large number of carbohydrates and glycoproteins, showed that this activity was not inhibited by any of the mono- or oligosaccharides tested. However, the glycoprotein avidin at the concentration of $4.8 \mu \mathrm{g} /$ $\mathrm{mL}$ was able to inhibit the $1 \mathrm{mg} / \mathrm{mL}$ hemagglutinating activity of the lectin. The demonstration that this activity in most marine alga lectins is inhibited only by glycoproteins has been previously reported $(4,15)$.

In the present study, we report a potent antinociceptive activity of a lectin from $A$. multifida. Similar effects have been demonstrated in lectins from other alga species such as that from the genus Bryothamnion (16). Thus, B. seaforthii and B. triquetrum significantly inhibited acetic acid-induced abdominal constrictions, and also inhibited the 1st and 2nd phases of the formalin test. These lectin effects were totally or partially reversed by naloxone, indicating the involvement of the opioid system. Similarly to that study (16), we also showed antinociceptive activity in the lectin from A. multifida, as assessed by the writhing test, as well as by the formalin and hot-plate tests. The effect was observed with doses as low as or even lower than $1 \mathrm{mg} / \mathrm{kg}$.

The hemagglutinating activity assays carried out with LEC, as previously shown, demonstrated that its activity was not changed by any of the mono- or oligosaccharides tested. However, the glycoprotein avidin at the concentration of $4.8 \mu \mathrm{g} / \mathrm{mL}$ inhibited the hemagglutinating activity of the lectin. Our results agree with other reports demonstrating that the hemagglutinating activity of the lectin from A. multifida is inhibited only by glycoproteins $(4,9,15)$.

Surprisingly, our results showed a partial and almost total blockade of the LEC antinociceptive action by avidin (a molecule rich in mannose residues) and D-mannose, respectively. Thus, the presence of D-mannose in the avidin molecule seems to be required for the effect of the LEC. These data suggest that carbohydrate-binding sites on the LEC molecule are important for its antinociceptive action.

The fact that avidin blocks only mannose-binding sites in the LEC molecule suggests the involvement of other carbohydrate residues in the LEC structure, possibly also involved in its antinociceptive effect (17). In addition, D-mannose significantly changed the LEC antinociceptive effect suggesting the involvement of this carbohydrate in the LEC effect, similarly to results of an earlier study and ours $(16,18)$.

Taken together, our results show that LEC is a potent central and peripheral natural antinociceptive compound, and indicate its potentiality as an analgesic drug. As far as we know, this is the first study showing the antinociceptive properties of a lectin from $A$. multifida, a marine red alga common to the Brazilian Northeast coast. Furthermore, we also demonstrated that this lectin effect was almost totally abolished by pretreatment with D-mannose, indicating that this carbohydrate (and possibly other ones) is somehow involved in the antinociceptive action of the lectin.

\section{Acknowledgments}

The authors are grateful to Ms. M. Vilani Rodrigues Bastos and Ms. Jacqueline Viana for technical assistance, and to the orthographic revision of Prof. M.O.L. Viana. 


\section{References}

1. Uhlenbruck G. Lectins, toxins and immunotoxins. Naturwissenschaften 1981; 68: 606-612.

2. Rogers DJ, Hori K. Marine algae lectins: new developments. Hydrobiologia 1993; 260/261: 589-593.

3. Hori K, Ito K. Some properties of lectins from marine algae. Hydrobiologia 1990; 204/205: 561-566.

4. Ainouz IL, Sampaio AH, Freitas ALP. Comparative study on hemagglutinins from the red algae Bryothamnion seaforthii and Bryothamnion triquetrum. Braz J Plant Physiol 1995; 7: 15-19.

5. Ainouz IL, Sampaio AH. Screening of Brazilian marine algae for hemagglutinins. Bot Mar 1991; 34: 211-214.

6. Nagano CS, Moreno FB, Bloch C Jr, Prates MV, Calvete JJ, SakerSampaio S, et al. Purification and characterization of a new lectin from the red marine alga Hypnea musciformis. Protein Pept Lett 2002; 9: 159-166.

7. Freitas ALP, Vieira LAP, Benevides NMB, Andrade MC, Silva DC, Melo MRS, et al. Analgesic activity of carbohydrate-protein complex from the red algae Bryothamnion seaforthii. XXXI Reunião Anual da SBBq. Fortaleza: SBBq; 2002. p 153.

8. Vieira LA, Freitas AL, Feitosa JP, Silva DC, Viana GS. The alga Bryothamnion seaforthii contains carbohydrates with antinociceptive activity. Braz J Med Biol Res 2004; 37: 1071-1079.

9. Costa FHF, Sampaio AH, Neves SA, Benevides N, Freitas AL. Purification and characterization of a lectin from the red marine alga Almansia multifida. Physiol Mol Biol Plants 1999; 5: 53-61.

10. Koster R, Anderson M, DeBeer EJ. Acetic acid for analgesic screen- ing. Fed Proc 1959; 18: 418-420.

11. Fasmer OB, Berge OG, Hole K. Changes in nociception after lesions of descending serotonergic pathways induced with 5,6-dihydroxytryptamine. Different effects in the formalin and tail-flick tests. Neuropharmacology 1985; 24: 729-734.

12. Hunskaar $\mathrm{S}$, Hole $\mathrm{K}$. The formalin test in mice: dissociation between inflammatory and non-inflammatory pain. Pain 1987; 30: 103-114.

13. Woolfe G, MacDonald AD. The evaluation of the analgesic action of pethidine hydrochloride (demerol). J Pharmacol Exp Ther 1944; 80: 300-307.

14. Ferrini R, Miragoli G, Taccardi B. Neuropharmacological studies on SB 5833, a new psychotherapeutic agent of the benzodiazepine class. Arzneimittelforschung 1974; 24: 2029-2032.

15. Benevides NMB, Leite AM, Freitas ALP. Atividade hemaglutinante na alga vermelha Solieria filiformis. Braz J Plant Physiol 1996; 8: 117-122.

16. Viana GS, Freitas AL, Lima MM, Vieira LA, Andrade MC, Benevides NM. Antinociceptive activity of sulfated carbohydrates from the red algae Bryothamnion seaforthii (Turner) Kutz. and B. triquetrum (S.G. Gmel.) M. Howe. Braz J Med Biol Res 2002; 35: 713-722.

17. Neves SA. Lectina de Amansia multifida Lamouroux: especificidade fina por carboidratos e ação farmacológica. [Master's thesis]. Fortaleza: Universidade Federal do Ceará; 2005.

18. Sampaio AH, Rogers DJ, Barwell CJ. A galactose-specific lectin from the red marine alga Ptilota filicina. Phytochemistry 1998; 48: 765-769. 